\author{
Аляикевіч T. $А$. \\ кандыдат філалагічных навук, \\ малодшы навуковы супрачоўнік аддзела тэорыі і гісторыі літаратуры \\ Цэнтра даследаванняў беларускай культуры, \\ мовы і літаратуры НАН Беларусі
}

\title{
АСАБЛІВАСЦІ ФУНКЦЫЯНАВАННЯ ПАРАНІМІЧНАЙ АТРАКАЦЫІ Ў ПАЭТЫЧНЫМ ТВОРЫ
}

Стаття присвячена питанню функиіонування паронімічної атракиії в поетичному тексті. Визначенні основні функиії паронімічної атракції. На прикладах показано те, як в поетичному тексті, завдяки образній атмосфері, забезпечується асочіативно-смислове навантаження $і$ на випадкові співзвуччя $і$ слова, як, в свою чергу, починають проявляти контекстуальну близькість, тим самим отримують додаткові конотації.

Ключові слова: паронімічна атракиія, конотація, поетичний текст.

Данная статья посвящена вопросу функционирования паронимической аттракции в поэтическом тексте. Выделены основные функиии паронимической аттракции. На примерах показывается, что в поэтическом контексте благодаря образной атмосфере обеспечивается ассочиативно-смысловая нагрузка на случайные созвучия и слова, которые, в свою очередь, начинают проявлять контекстуальную близость, тем самым получая дополнительные коннотации.

Ключевые слова: паронимическая аттракция, коннотаџия, поэтический текст.

This article is devoted to the functioning of paronymic attractions in the poetic text. The main functions of paronymic attractions were noticed. The examples show that, in thecontext, with the use of poetic atmosphere, associative semantic meaning is ensured at random words and consonance, which, in turn, begin to show contextual proximity, by obtaining additional connotations.

Keywords: paronymic attraction, connotation, poetic text.

Крэатыўнай па сваёй прыродзе з’яўляецца паэзія XX-XXI стагоддзяў. Творчасць многіх паэтаў сёння арыентавана на актыўныя моўныя пошукі і моўныя пераўтварэнні. Паэт XXI стагоддзя гэта ўважлівы філолаг, i інтуітыўны лінгвіст, які раскрывае шмат- 
мернасць мовы, чый творчы імпульс сягае ў глыбінныя трансцэндэнтныя прасторы мовы.

Пры даследаванні фанічнай арганізацыі твораў узнікае шмат пытанняў: 3'яўляецца гукавая ўпарадкаванасць аўтаматычным стылістычным прыёмам ці яна ўзнікае адвольна пад уздзеяннем моўных і псіхалагічных законаў ва ўспрыманні чытача?! Ці не 3'яўляецца такая упарадкаванасць уяўнай, ці невыпадковыя графічныя і акустычныя супадзенні ў гучанні словаў, што падбіраюцца аўтарам, каб дакладна і поўна выразіць сэнсавы бок паэтычнага выказвання? Сапраўды толькі рыфма з'яўляецца наглядным паказчыкам свядомага і выбарчага выкарыстання гукавой сіметрыі ў якасці канстанты паэтычнай мовы, у астатніх выпадках меркаванні даследчыкаў патрабуюць нагляднага пацверджання. 3 аднаго боку, на наўмыснае выкарыстанне гукавых паўтораў і розных спосабаў гукавой аранжыроўкі ўказвалі самі паэты (В.Брусаў, А.Белы, А.Блок,У.Маякоўскі і інш.) і даследчыкі верша. 3 другога боку, нельга не ўлічваць і ўзнікненне выпадковай гукавой сіметрыі пад уздзеяннем фактару “адзінства і цеснаты вершаванага рада” (Тынянаў). Такім чынам, можна лічыць, што гукавая ўпарадкаванасць узнікае пад уздзеяннем розных фактараў: у адным выпадку паэт канструіруе яе абсалютна наўмысна, выкарыстоўваючы розныя віды паўтору ў якасці адпраўной кропкі для напісання верша, у іншым выпадку, інтуітыўна падпарадкоўваючыся метра-рытмічнай інэрцыі, надае радку, страфе альбо ўсяму вершу гукавую ўпарадкаванасць. На нашу думку, у працэсе творчасці мастацкае мысленне паэта i яго слых утвараюць непарыўнае адзінства, якое знітоўвае паміж сабой усе складнікі паэтычнай мовы, уключаючы і гукапіс.

У дадзеным артыкуле мы паспрабуем прааналізаваць такія выпадкі ў арганізацыі гукапісу паэтычнага твора, калі аўтар тэксту мэтанакіравана збліжае ў ім сугучныя словы 3 той ці іншай стылістычнай устаноўкай. Асацыятыўная сувязь абумоўліваецца падабенствам, сумежнасцю альбо супрацьпастаўленнем гукавога боку моўнага знаку. Найбольш гэты спосаб семантычнага збліжэння 
вядомы як з'ява паранімічнай атракцыі (паронімы (у шыр.зн.) словы, блізкія па гучанні, але розныя па семантыцы) альбо “паэтычнай этымалогіi (ад грэч. Etymon - ісціна i logos - паняцце, вучэнне) - адзін з відаў тропа, у якім перанос значэння з аднаго слова на другое адбываецца на аснове гукавой іх блізкасці. Такія семантычна далёкія, але блізкія па гучанні словы звычайна стаяць у вершаваным радку побач, выяўляючы дадатковыя сэнсавыя i эмацыянальныя адценні” [Рагойша 2004: 131-133].

Блізкасць паміж сэнсамі словаў матывуецца гукавымі супадзеннямі. Гукавая матываванасць не можа быць аформлена ў свядомасці чытача ў выглядзе выразнага паняцця - прыкметы i ўяўляецца толькі як нейкая семантычная агульнасць. Акрамя таго, эксплікацыя гукавых сродкаў - гэта пераважна аперацыянальны прыём, якім даволі рэдка карыстаецца звычайны чытач. Пранімічная атракцыя заснавана не на выпадковым супадзенні словаў на фоне іх відавочнага адрознення, а на "відавочным” падабенстве словаў, што ўтвараюць семантычную атракцыю. “Пра такія словы, што ўсё часцей і нетрадыцыйна акцэнтуюць у паэтычных тэкстах XX стагоддзя сваю гукавую блізкасць менавіта як словаў, можна гаварыць, што яны не столькі супадаюць па аднаму-двум і нават тром-чатыром і болей гукаў, колькі адрозніваюцца адзін ад аднаго толькі па тром-двум, а то і па аднаму адзінкаваму гуку (літары)" [Григорьев 1979: 242]

Аналіз функцыянавання паранімічнай атракцыі базуецца на функцыянальным уздзеянні - вобразным, эстэтычным. Што ўяўляюць сабой стылістычныя магчымасці паранімічнай атракцыі ў паэтычным тэксце? Агульнымі для творчасці сучасных паэтаў 3'яўляюцца наступныя функцыі паранімічнай атракцыі:

\section{1.Функцыя дакладнай рыфмоўкі:}

\section{Талент - гэта праклён}

Паласатага д'ябла.

Намагаещйа плён,

Каб душа не азябла.

Талент - гэта палон... [Барадулін 2005: 218]; 
І раўніну выгарбіиь курган

I крумкач накрумкае урраган [Барадулін 2005: 37].

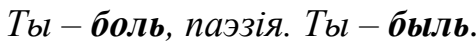

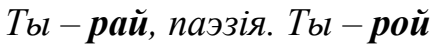

Адвечных дум, дзе мы згараем.

$T b l-\boldsymbol{ж а л ь , ~ п а э з і я . ~ T b l - ж с а р . ~}$

Я па тваім хажу вуголлі.

$T b l-c y м$, паэзія. $T b l-c y d$

$T b l-\boldsymbol{я d , ~ п а э з і я . ~} T b l-c a d$

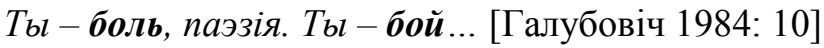

Дзівіщуцуа дзень

авадзень

у грудзі ияаляе мне -

камікадзе. [Разанаў 2012: 125]

Нешта схавалі?!

хвалі

зганяюиь на бераг

шум. [Разанаў 2012:126]

Дзе на месиьы палацяу

будующиа ў спешцы палацы,

заіскрылася песня

расінкай на елачнай лапцы-

скрыпящь мае лапці... [Бічэль-Загнетава 1979: 119] 
2.Функцыя стварэння эфекту алітэрацыі:

Страшна ступащь па расе

На золку -

Зорак асколкі [Дэбіш 2012: 37].

Валізкі вялізазныя:

Вызваляе

бліскаўка з хмарай

гром [Разанаў 2012: 126]

Перавысіць не пніся высі, // Прагна не перасыцься сытой [Барадулін 2005: 50]; I цемя у ияжкай цемры кволае [Барадулін 2005: 63]; Гром здзіўлены заікаўся на уизрымме [Барадулін 2005: 126]; Дзе сумёціцца смецце [Барадулін 2005: 89].

3.Функцыя арганізацыі ўнутранай рыфмы:

Наш дух вячысты // 3 вачыстылм злом [Барадулін 2005: 174]; Душа да пакуты прыкута [Барадулін 2005: 56]; Дзе абначаваць ласуну Лесуну [Барадулін 2012: 210]; Абыходзіцьь вір знявер'я бокам [Барадулін 2005: 218], Горы угарбелі, мір несучь [Барадулін 2005: 94], Пачуй нас і пакарчуй [Барадулін 2005: 91].

Дзівіичиа дзень

авадзень

у грудзі изаляе мне -

камікадзе [Разанаў 2012:129]

Нешта схавалі?!

хвалі

зганяюиь на бераг

шум [Разанаў 2012:126]

Ручай, выручай!.. -

Дадому

знаходзь дарогу [Разанаў 2010:25] 
Я прынёс іх з ляснога дрымучага свету,

дзе з брусніцамі ніцымі - жар верасоў.

Падасінавікаў у чырвоных барэтах

Пад старою асвінай асінай знайшоў [Танк 1979: 248].

4.Функцыя сродкаў выражэння асноўнай ідэі твора.

Лыжка драмаць не павінна ў дармовым супе [Барадулін 2005: 54], Ластаўка ласкаю гнёзды уее [Барадулін 2005: 48], І віно ад віны, і віна ад віна [Барадулін 2005: 50], Недзе ля нахмураных хмар [Барадулін 2005: 58], Іржсавы іржюэўнік [Барадулін 2005: 65], Бо вусны - вусце думкі [Барадулін 2005: 84], Хай спрахне наш страх [Барадулін 2005: 91], Літасць - // Стомленая лютасць змроку [Барадулін 2005: 218], Зорнай жарсці ж⿻ар [Барадулін 2005: 42];

Поле

У тваім замкнёным коле

Нашы душы, думы і дамы [Макаль 1982: 48].

Сугучныя словы ў гэтай функцыі даволі выразныя, яркія, часам афарыстычныя, дапамагаюць сфармуляваць асноўную думку асабліва дакладна. Узнікае новае канатацыйнае значэнне, такія словы становяцца гукавой метафарай.

5.Функцыя стварэння асацыятыўна-семантычных палей, якія спрыяюць перабудове семантычных значэнняў і стварэнню пэўных канатацый.

На аснове сугучнасці адбываецца ўзаемапранікненне семаў далёкіх па сэнсу словаў. У такой функцыі названым прыёмам вельмі часта карыстаецца Алесь Разанаў. У жанры вершаказа паэт імкнецца аднавіць сувязь паміж рознымі з'явамі: ён аб'ядноўвае гукі, вобразы, словы вакол асобных сэнсавых цэнтраў, што ўключаюцца ў паранімічныя адносіны для выяўлення семантычнай блізасці. Напрыклад:

\section{"Верасень"}

"У верасні, калі дацвітаюџь апошнія кветкі, // на лясных пагорках, выжарынах, расияробах, // усиілаючы дол каляровым ворсам, // красуе верас. 
Сярод астатніх распазнаных раслін верас // нібы версэт сярод вермаў: у параўнанні // з дрэвамі ён - трава, у параўнанні з травою - // дрэва, і у параўнанні з іхнімі “веравызнаннямі” // яго “веравьззанне” - ерась” [Разанаў 2009: 62]. У дадзеным вершаказе гукавы комплекс ключавога слова верасень нітуе вакол сябе такія сугучныя словы як верас, ворс, версэт, ерась, версія. Названыя словы ў звычайнай мове не маюць ніякай роднаснай сувязі ні паміж сабой, ні з ключавым словам. Аднак у паэтычным кантэксце дзякуючы вобразнай атмасферы забяспечваецца асацыятыўна-сэнсавая нагрузка на выпадковае сугучча, і словы пачынаюць “выпраменьваць” сваю кантэкстуальную блізкасць, тым самым набываючы дадатковыя канатацыі. Альбо такі прыклад:$$
\text { “Хлеб” }
$$

“Хлеб святы, хлеб вялебны, і усё, што спалучана з ім, што // “злеплена” з ім, адбываециа // як абрад, як набажэнства, як малебен. // хлеб хвалебны: яго шанующь і хваляцьь усе плямёны - $i$ дулебы, і вялеты, і лахвічы. // хлеб лепшы: з усіх страў, з усіх наедкай, // у ім жыичёе (и̧і на іншай мове Leben). // ён есци, смокчаџиа, грызещиа, “хлябаециа” $і$ генетычна памятае свій радавод, сваю баџькаўшчыну - глебу. // На выгляд хлеб чорны, але nа сваёй суінасиі // бель”" [Разанаў 2009: 29]. Слова хлеб, выступаючы сэнсавым цэнтрам, “уцягвае” ў адносіны паранімічнай атракцыі наступныя словы: вялебны, малебен, хвалебны, дулебы, вялеты, лепшы, Leben, “хлябаецица”, глебу. "Паронімы, ужо загадзя аб'яднаны ў індывідуальным слоўніку паэта сваёй матэрыяльнай блізкасцю, правакуюць, падказваюць, у пэўнай меры прадвызначаюць накірунак асацыяцый, якія развівае паэт, хоць і не абмяжоўваюць ягонай свабоды” [Григорьев 1979: 272].

Пералічаныя функцыі паранімічнай атракцыі дзейнічаюць не ізалявана: яны пекрыжоўваюцца, узаемадапаўняюць адна другую. Напрыклад, у “Адвечнай песні“" Я.Купалы чытаем:

Дзылн-дзын-дзын, звіні, як жалеза,

Золата, звонка-званіста; 
Звіні па жалезных нарэзах,

Дзын-дзын, звіні у звон ірдзіста. [Купала 2001: 292]

Алітэрацыя на гукі [3, дз, н, ж] у радках садзейнічае стварэнню эфекта гукапераймання - бразгання грошай, які з'яўляецца асноўным у дадзеных радках. Акрамя таго сугучныя словы падпаракоўваюцца і ўнутранай рыфме.

Майстэрства паэтаў дэманструе сэнсавае збліжэнне рознакаранёвых словаў на аснове іх вобразнага пераасэнсавання, а не проста гульню сугуччамі, хоць апошняя, па словах рускага паэтафутурыста В.Хлебнікава ёсць з'ява анталагічная [Хлебников 1986: 619], у той час як "словатворчасць крэатыўная па сваёй прыродзе” [Хлебников 1986: 619]. Паранімічная атракцыя гранічна ўшчыльняе змест, паколькі кожны яе элемент у лаканічным выглядзе ўтрымлівае ў сабе сціснутую асацыятыўную энергію. Гэты кампанент творчасці адлюстроўвае спецыфіку ідыястылю паэтаў.

Парнімічная атракцыя ў якасці канструктыўнага прынцыпу даволі частая з'ява ў творчасці паэтаў XX-XXI стст. В.П.Грыгор'еў выказвае думку пра тое, што паэты XX стагоддзя ў большай ступені, чым паэты-сімвалісты, усведамляюць не толькі шматграннасць сэнсавых эфектаў паранімічнай атракцыі, але, перш за ўсё, мастацкія магчымасці гэтага прыёму.

Паранімічная атракцыя толькі адзін 3 элементаў у цэлым шэрагу спосабаў мастацкай экспрэсіі, 3 якіх складаецца багацце і разнастайнасць паэтыкі твора. Аднак нават такі пералік магчымасцей паранімічнай атракцыі, які прадстаўлены вышэй, сведчыць пра незвычайна шырокі дыяпазон і высокі стылістычны патэнцыял гэтага элементу.

\section{БІБЛІОГРАФІЯ}

Барадулін 2005 - Барадулін Р. Ксты / Р. Барадулін. - Мінск: Рым.-катал. Парафія св. Сымона і св. Алены, 2005. - 472 с.

Барадулін 2012 - Барадулін Р. Карані цішыні... Вершы / Р. Барадулін // Дзеяслоў. - 2012. 一 №1. - C. 203-218.

Бічэль-Загнетава 1979 - Бічэль-Загнетава Д. Браткі: Вершы і паэмы. - Мінск:

Маст.літ., 1979. -240 с. 
Галубовіч 1984 - Галубовіч Л. Таемнасць агню / Л.Галубовіч. - Мінск: Маст.літ., 1984. $-86 \mathrm{c}$.

Григорьев 1979 - Григорьев В.П. Поэтика слова / В.П. Григорьев. - М.: Наука, 1979. $-343 \mathrm{c}$.

Дэбіш 2012 - Дэбіш В. праз дождж: вершы / В.Дэбіш. - Брэст: Брэсцкая друкарня, $2012-175 \mathrm{c}$.

Купала 2001 - Купала Я. Адвечная песня. Вершы і паэмы / Я.Купала. - Мн.:

Маст.літ., 2001. - 351 с.

Макаль 1982 - Макаль П. Выбраныя творы: У 2-х т. - Т.1.: Вершы. - Мінск:

Маст.літ., 1982. - 287 с.

Рагойша 2004 - Рагойша В.П. Паэтычны слоўнік / В.П. Рагойша. - Мінск: Бел. навука, 2004. - 576 с.

Разанаў 2010 - Разанаў А. Воплескі даланёю адною: Пункціры / А. Разанаў. Мінск: І.П.Логвінаў, 2010. - 76 с.

Разанаў 2009 - Разанаў А. Пчала пачала паломнічаць: вершаказы / А. Разанаў. Мінск: І.П.Логвінаў, 2009. - 132 с.

Разанаў 2012 - Разанаў А. Столькі і гэтулькі. Пункціры / А. Разанаў // Дзеяслоў. 2012. - №2. - C. 122-130.

Танк 1979 - Танк М. Збор твораў. У 6-і т. Том 3. Вершы 1954-1964. - Минск : Маст.літ., 1979. - 560 с.

Хлебніков 1986 - Хлебников В. Творения / В. Хлебников. - М. : Сов.писатель, 1986. $-623 \mathrm{c}$.

Стаття надійшла 3 вересня 2013 р. 